\title{
A Correlational Study of the English Listening and Speaking Anxiety in Rural Areas
}

\author{
Tuan Muhammad Hanif Tuan Ab Hamid ${ }^{1} \&$ Faizah Idrus $^{1}$ \\ ${ }^{1}$ Faculty of Education, International Islamic University Malaysia, Malaysia \\ Correspondence: Faizah Idrus, Faculty of Education, International Islamic University Malaysia, 53100, Gombak, \\ Selangor, Malaysia.
}

Received: December 18, 2020

Accepted: January 7, 2021

Online Published: January 18, 2021

doi: $10.5539 /$ elt.v14n2p9

URL: https://doi.org/10.5539/elt.v14n2p9

\begin{abstract}
English proficiency amongst Malaysian is debatably on a decline. Possible causes of this phenomenon are extensively argued. Thus, renewed interest towards English language anxiety, an internal factor of learners' level of intensity in listening and speaking skills, can sometimes be overlooked. An investigation was conducted on selected secondary schools' students in Selangor, a state in Malaysia. The schools lacked facilities and meagerly equipped with basic resources and facilities. A total of 311 non-national examination takers students from three different schools were selected. A set of questionnaire were distributed which adopted a composite of foreign language anxiety surveys, measuring their level of anxiety towards the English language classroom according to the four language skills (reading, listening, speaking, writing). The results were measured and the scores were tabulated. A correlation was established between the listening anxiety and speaking anxiety skill from the scores. This finding explored the possibility of reducing language anxiety in two skills by intervening in only one instance which can be helpful in reducing the time spent on managing the English language classroom anxiety. However, further studies should be conducted in order to improve the validity of this result.
\end{abstract}

Keywords: English Language Anxiety, second language learning, rural area, English as a second language, issues in second language learning, profile

\section{Introduction}

\subsection{Background of the Study}

Education system in Malaysia, considers the English language as an important element of the system for the country (Thirusanku \& Yunus, 2012; Hashim, 2004) due to its status, as Malaysia is one of the countries in the world that formally uses English as a second language. It is also a by-product of bilingual education practiced by the educational system (Darmi \& Albion, 2013; Ali, 2000). However, this status does not deter the developing fear on the decline in English proficiency among Malaysians, specifically for fresh graduates (Darmi \& Albion, 2013). Interventions in terms of policies have been initiated by the Malaysian government to curb this decline, namely the PPSMI (English for Teaching Science and Mathematics). However, its outcomes were deemed unsuccessful by reports that examined its effectiveness (Yunus \& Sukri, 2017) and at the same time, further widening the gap between rural and urban students. It is a widely known phenomenon that rural area students struggled to grasp the meaning of the English language lessons in that English is more of a foreign language (Tan, 2009) as compared to their urban counterparts.

English Language Classroom Anxiety has become a prevalent consideration for factors that might impede the English language learning for non-native speakers. This is one of the more frequently researched issue in second language acquisition as it is relevant to Malaysians where English language learning occurs in a formal and informal settings (Ratnawati, 2004; Pandian 2008).Thus, this suggests the possibility that such specific phenomenon might also exist in the Malaysian classroom, where anxiety had been suggested to hinder language acquisition during a lesson, a particular form of apprehension that is common in a language classroom (Krashen, 1982). Horwitz, Horwitz and Cope (1986) carried out subsequent studies and constructed the Foreign Language Classroom Anxiety Scale (FLCAS) which measured apprehension, worry, and anxiety of students inside an English language classroom. More recent studies by Landstrom (2016), Cheng (2015), Kimura (2008), Woodrow (2012) and Mak (2011) reverberated the existence of anxiety in English language classroom in different language skills i.e. Reading, Listening, Speaking and Writing, which consequently impeded language learning of 
the students. These studies demonstrated the unsettling nature of learning a new language (Dewale \& Thirtle, 2009) hence validating the issue discovered by Horwitz, Horwitz and Cope (1986). Anxiety is focal to the current study as its potential to disrupt students' English language learning is quite substantial. This is in aligned with the investigation of the possible factors that might cause the decline in English proficiency among Malaysians.

\subsection{English in Malaysian Education}

Malaysia has established the status of English as a second language due to the British colonial rule which implemented the language as the language for administration and education. Post-independence Malaysia still saw the extensive use of English in Malaysia, which was reinforced by government's policies, specifically the educational policies as the government opined that it was a functional interethnic communication tool (Subramaniam, 2007; Wong \& Thambyrajah, 1911). The decline of English proficiency in recent decades implores an examination into the 11 years of formal English education in the national curriculum and its effectiveness, as English proficiency is a predictor for employability due to the insistent demands from employers (Hashim, 2004; Padian, 2008; Ali, 2000), and not reliant solely on university grades (Guan, 2016). The decline of English was attributed to the change of educational policy on the instructional language, where English language becomes supplementary to the national language (Foo \& Richards, 2004) which in turn eroded the use of the language in educational spheres. The Rahman Talib Report 1960 and the National Education Act 1996 were also attributed to the shift of English language into an ancillary role compared to the national language (Hashim, 2004; Pandian, 2008). Thus, it might have caused a decline in the use of the English language among Malaysians. This study however is interested in the state of the learners themselves; the psychological experience of the students when learning the English language and whether it might have a considerable impact on the proficiency of the students.

\subsection{English Language Anxiety}

Second/Foreign Language Anxiety is a pertinent issue in the English as a Second/Foreign Language field (ESL/EFL) as it is widely researched in the recent decade. It was pioneered by Horwitz, Horwitz and Cope (1986) who established a functional scale that could measure Foreign Language Classroom Anxiety Scale (FLCAS) of learners inside a classroom. The FLCAS then became the instrument used for measuring language classroom anxiety by researchers in the ESL/EFL field and its reliability has been established. Horwitz et al. (1986) defined anxiety as feelings of apprehension, nervousness, worry, or tension, subjective to the learner, which stimulates the nervous system. The definition provided is distinct from Test Anxiety, which Sapp (1993) defined as anxiety manifesting from harsh emotions which impacts the emotion and physiology of the learner. This distinction is crucial as test anxiety manifests in all situation where a learner's knowledge and performance are measured, whereas Foreign Language Classroom Anxiety by Horwitz et al. (1986) is anxiety manifesting generally inside a second/foreign language classroom which is non- native to the learners. McIntyre and Gardner (1994) further illustrated the relationship between anxiety and language learning using Tobias' (1986) cognitive model in which anxiety inhibits the language learning by interfering the language input and the language output as illustrated in figure 1.0 below.

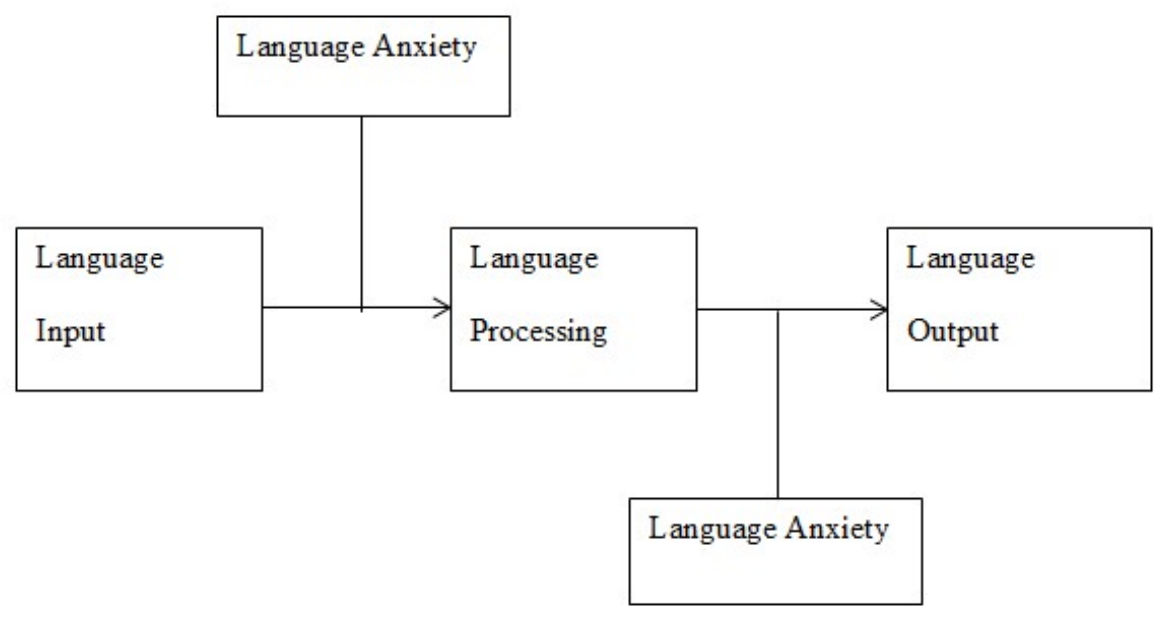

Figure 1. Intrusion of Language Anxiety in the Language Learning Process 
It is clear that anxiety interferes with both the language input and the language output of a learner in the second/foreign language classroom, in contrast with test anxiety which only occurs during performance evaluation of learners for any subject matter. Through demonstration of anxiety interference in a second/foreign language learning process, McIntyre and Gardner 1993 further reinforce the understanding that anxiety disrupts the language input and language output of the learners in the classroom, and this might also occur during the listening (input) and speaking (output) classroom in rural area secondary schools in Selangor.

Kimura (2008) conducted a study on foreign language anxiety and the listening skills on 452 university freshmen in Japan, from two different faculties at the end of a semester, and found that students from both faculties experience anxiety when listening to English, the foreign language they studied weekly at the university. Three factors were uncovered from the study, which are emotionality (feeling of discomfort, apprehension, alienation and intimidation), worry (cognitive perceptions) and anticipatory fear (future related thoughts which induces anxiety) which caused anxiety in the students during the listening activity and diminished the listener's capacity to pay attention to the listening task at hand. These two studies involved two age groups, the younger learner and the older learner, and showed the effect of anxiety on listening. The result was significant and affected language performance of the studied groups, regardless of their age.

Woodrow (2012) investigated anxiety on oral performance of English language learners in Australia. 275 university students participated and the result reported a significant negative relationship between anxiety and oral performance, including communications outside of classroom settings. The main stressor of in-class oral performance was the teacher's presence as the evaluator of the oral task, and the main stressor for oral performance outside of the classroom was communicating with a native speaker. Woodrow distinguished anxiety in and outside the classrooms by establishing a non-significant correlation between the two anxieties to further validate Horwitz et al. (1986) point on the distinction between general anxiety and language classroom anxiety.

From the reviewed studies, it is clear that both language skills were also specifically affected by anxiety, and the similar stressor for both studies were language performance of the students during classroom activities where the anxiety pervaded their focus on the language tasks and then diminishing their language skill performance inside the classroom. This indicates the debilitative effect of second/foreign language classroom including specific language skills, as demonstrated by McIntyre and Gardner' in figure 1.0 above, where anxiety interferes at the language input and language output of the learners. This is in line with the focus of this current study on the listening and speaking skills.

\subsection{Why Anxiety}

The condition in rural area schools are disadvantageous due to its infrastructure and its resources, an inverse condition to its urban counterparts, as UNESCO (2013) charted this inadequacy as a global phenomenon, which inadvertently weaken the examination performance of rural school areas (Aziz \& Swanto, 2017). This inadequacy also affected English language classroom effectiveness as the lack of resources (Wreikat et al., 2014; Ratnawati, 2004) contributed to lower exposure to the language amidst the already minimal existence of the language outside the classroom where English is almost a foreign language in the rural areas (Pandian, 2008). Selangor is one of the more developed states in Malaysia (Hussain, Nabila, \& Abdullah, 2018) and internal migration rate is high, where urban areas received a large part of the migration (Department of Statistics Malaysia, 2020). Some rural area students will leave the area to find better job opportunities; therefore it is also important that they are equipped with adequate English to ensure a feasible chance of employment as employers underscores the importance of English proficiency (Hashim, 2004; Pandian, 2008; Ali, 2000). Identifying the correlation between listening anxiety and speaking anxiety can help in determining what intervention can be taken in order to reduce it effectively, without placing excessive effort on tackling both language skills' anxieties. These two skills are selected due to a generalised understanding that proficiency in a certain language is hinged on the ability to produce the target language with a certain level of competency (Leong \& Ahmadi, 2017). Most studies revolving second/foreign language anxiety in Malaysia involved the tertiary educational demographic, thus, a literature gap exists for studies involving the secondary school students, especially in the rural area.

Students in rural Malaysia are largely under-exposed to the English language, both in terms of language use (Ali, 2000; Thien \& Ong, 2015) and materials (Wreikat, Kabilan, \& Abdullah, 2014). The main source of exposure for the rural area students are often their English teacher, during the English lesson (Musa, Khoo, \& Azman, 2012; Pandian, 2008) which demonstrates the point Tan (2009) made about the social status of English in the rural area as a Foreign Language. This might develop anxiety in the students due to unfamiliarity to the language, especially in terms of input and output of the language (listening and speaking skills). Consequently, the study poses the question; is there any correlation between listening skill anxiety and speaking skill anxiety? The 
investigation can assist in formulation of targeted interventions inside the classroom, which can be applied to classrooms in the rural areas. This will help the resource-exposure disadvantaged rural area secondary school students to achieve an adequate mastery of the language which can help them to advance in their life post-secondary education, whether in academia or employment and improve the English proficiency of Malaysians principally. Thus, the main aim of the study is to identify the relationship between listening and speaking anxiety among selected rural area secondary school students in Selangor, Malaysia.

\section{Method}

\subsection{Research Design}

This study is quantitative in nature, which utilises the cross-sectional survey method to distinguish trends in a population (Cresswell, 2005, as cited in Marwan, 2007). The cross-sectional survey method is effective and efficient in examining a large amount of data and is frequently used in language education research. 311 questionnaires were retrieved after distribution to the three schools situated in three different rural area districts in Selangor $(\mathrm{N}=110000)$ after a $92 \%$ degree of confidence is followed, and a $5 \%$ margin of error was set. This method suits the objective of the research.

\subsection{Participants}

Purposive sampling was used to answer the research question, where non-national examination taker secondary school students in rural area Selangor were sampled from three different school types in three different rural areas in Selangor. Students aged 13,14 and 16 were selected as they were not involved in major national examinations which can cause test anxiety as mentioned by Sapp (1992), which is distinct from Second/Foreign Language Classroom Anxiety. This ensures the anxiety that is measured does not collate with Test Anxiety which have different framework and implications.

\subsection{Instrument}

The instrument used for this study was a composite questionnaire, adapted and adopted from five different language anxiety scale, namely the Foreign Language Anxiety Classroom scale by Horwitz, et al. (1986), English Language Listening Anxiety from Kimura (2008), English Language Speaking Anxiety by Mak (2011), English Language Reading Anxiety by Saito, Horwitz \& Garza (1999) and English Language Reading Anxiety by Lee (2005). A total of 55 items were adapted and adopted from all the scales, and were separated into 4 sections, excluding the demographic section and was valued with a 5-point Likert item scale. The questionnaire was also translated into the Bahasa Malaysia (the Malay Language) in order to increase comprehensibility. The sections and items are illustrated in table 1 below.

Table 1. The Number of Items per Questionnaire Section

\begin{tabular}{cc}
\hline Sections & Number of Items \\
\hline Demographic Data & 9 \\
Listening Anxiety & 12 \\
Reading Anxiety & 10 \\
Speaking Anxiety & 18 \\
Writing Anxiety & 15
\end{tabular}

A pilot study was conducted on 144 students from SMK Sungai Pusu to establish the validity and reliability of the questionnaire. The outcome was a value of 0.86 on the Cronbach Alpha analysis, which is acceptable in social science research.

\subsection{Data Collection Procedure}

The questionnaire was distributed to three different schools, where all three schools, which will be simply referred to HL, KKB and KS schools, which are situated in different rural areas in Selangor. Several teachers assisted with the questionnaire distributions, and the questionnaires were collected the following day in order to not disrupt the teachers' classes. The survey was then later returned and the data coded and administered into SPSS.

\subsection{Data Analysis}

Data was analysed using SPSS, and its sum score for each response was calculated according to the language skills, and then divided into three levels of anxiety; low, moderate and high anxiety, with definitive cut-off scores to categorise it accurately. Then, the scores of listening anxiety and speaking anxiety were analysed using 
the bivariate correlation function in SPSS. The results were tabulated and further analysed. The cut-off scores is shown in table 2.

Table 2. Cut-Off Scores for Each Language Skills

\begin{tabular}{cccc}
\hline Language Skill & \multicolumn{3}{c}{ Anxiety Level Scores } \\
\hline Listening & Low & Medium & High \\
Reading & $13-28$ & $29-44$ & $45-60$ \\
Speaking & $11-23$ & $24-36$ & $37-49$ \\
Writing & $25-46$ & $47-68$ & $69-90$ \\
\hline
\end{tabular}

\section{Results}

\subsection{Results of Anxiety Levels in English Language Classroom}

The data was collected and tabulated. The responses were cumulated in table 3, where all four language skills and its respective anxiety level is categorized into low, medium and high.

Table 3. Frequency of Each Language Skill and Its Anxiety Level

\begin{tabular}{cccc}
\hline Language Skill & \multicolumn{3}{c}{ Anxiety Level Scores } \\
\hline Listening & Low & Medium & High \\
Reading & $44(14.1 \%)$ & $215(69.1 \%)$ & $51(16.4 \%)$ \\
Speaking & $59(19.0 \%)$ & $183(58.8 \%)$ & $68(21.9 \%)$ \\
Writing & $59(19.0 \%)$ & $211(67.8 \%)$ & $40(12.9 \%)$ \\
& $68(21.9 \%)$ & $202(65.0 \%)$ & $40(12.9 \%)$
\end{tabular}

All language skills reported medium to high levels of anxiety in selected rural area schools in Selangor, except for writing skills, where students experienced low to medium levels of anxiety during the classroom session. For both listening and speaking classes, they both reported medium to high levels of anxiety.

\subsection{Correlation Analysis of Listening and Speaking Anxiety Scores}

The correlational analysis was conducted on the two language skills, listening and speaking for any correlation in their anxiety. The two categories' sums were scored and was analysed for bivariate correlation as tabulated in table 4.

Table 4. Pearson Correlation for Listening and Speaking Scores

\begin{tabular}{llll}
\hline Correlations & & & \\
\hline \multirow{2}{*}{ SLC (Binned) } & Pearson Correlation & 1 & SSC (Binned) \\
& Sig. (2-tailed) & & $.512^{* *}$ \\
& $\mathrm{~N}$ & 311 & .000 \\
SSC (Binned) & Pearson Correlation & $.512^{* *}$ & 311 \\
& Sig. (2-tailed) & .000 & 1 \\
& $\mathrm{~N}$ & 311 & 311 \\
\hline
\end{tabular}

**. Correlation is significant at the 0.01 level (2-tailed).

The sig value was 0.00 where $\mathrm{p}=<0.01$. There was a significant positive correlation between the scores in the listening anxiety skill and the scores in the speaking anxiety. An increase in the scores in one language anxiety skill can cause an increase in the subsequent language anxiety skill.

\section{Discussion}

Listening and speaking are interdependent especially in communication. English communication also relies on these two skills when a speaker of a language produces speech in the target language (Leong \& Ahmadi, 2017). Since listening is the input source for oral speech, it is interesting to investigate the possible relationship that might exist between listening anxiety and speaking anxiety. 
The anxiety scores in the listening section correlates positively to the score in speaking anxiety section. As anxiety in the listening section increases, the anxiety in the speaking section also increases. This correlation is important as in communication, listening is considered as the input skill and speaking is the output skill. An interruption via anxiety in the listening skill could influence the performance in the speaking skill, as the anxiety experienced during the listening classroom or activity could be a factor in the rise of anxiety during speaking activities. It can be explained by the disruption caused by anxiety during listening activities which might hinder the information processing needed to participate in social conventions, therefore reducing the possible responses that can be uttered in a short, determined time. Social speech is real time and spontaneous (Pan, 2016) and this might induce anxiety inside the students during speaking classrooms if they feel pressured to respond with insufficient information due to interruption caused by anxiety during the listening period.

This also indicates that speaking anxiety can also exist due to anxiety that surfaced during listening activity, and does not only exist specifically during the moment of interaction the students experience occurs. This could also mean some anxiety that arises during speaking activities might have already existed from the listening session. Inside the classroom, speaking activities must be prompted through instruction by the teacher and it involves the listening process to presuppose the speaking activities, and if it already existed during the listening process, i.e. if the students are already feeling anxious when listening to the instructions before the actual speaking activity, the probability of students feeling anxious during the speaking activity might also increase, as there is significant correlation between the existence of anxiety in both language performance. Therefore anxiety that exists in the listening session might entail the anxiety manifesting in the speaking session.

The listening skill is an input skill, and it is a part of communication in the second language. In order to speak, input must be obtained in order to have effective communication. Ye and Pan (2016) mentioned that fast paced speech can cause anxiety, and disengage the students from listening. When the students' listening is impeded by anxiety, they do not have sufficient input for speech. This lack of information that is needed to speak might cause anxiety inside the students which in turn, impairs the students' speech. This can be one way in which listening anxiety could influence speaking anxiety as both skills are vital in oral communication. Therefore when one skill is impaired, it might affect the other skill. Therefore, an interruption in the input of the language can possibly influence the output of the language.

The finding of this study offers a new perspective into the pedagogical approach to anxiety inside the Malaysian English classroom, specifically in rural areas. It is interesting to note that if the two anxiety skills are correlated, then a decrease in anxiety for one skill i.e., the listening skill, might reduce the anxiety in the other related skill i.e., the speaking skill. If there is a relationship, then by alleviating the anxiety or reducing the anxiety in the listening skill, there is a possibility that the speaking skill anxiety could also be reduced as a consequence of the reduction of anxiety in the input skill. Therefore by reducing the anxiety in one skill, the teacher can manage the class efficiently without spending too much effort on alleviating anxiety for multiple skills which will be more time consuming. This postulation allows further exploration of intervention methods for reducing second language anxiety inside the rural area classroom, and the Malaysian English classroom in principle.

The listening and speaking skills are two crucial English language skills in the communicative and oral communication is one of the indicators of proficiency in the language (Leong \& Ahmadi, 2017). The Pearson Correlation coefficient obtained from the analysis indicated a positive significant relationship between the two anxiety skills, where an increase in the listening anxiety causes a rise in the speaking anxiety.

The correlation between English listening anxiety and English speaking anxiety seem to indicate a possibility of the anxiety inside a language learner might exist before the language skill is exercised from another apprehension-inducing situation in a different language skill. Other possibility is that the reduction of anxiety in one language skill can amend or inhibit anxiety from manifesting inside a student during another language skill session. Teachers can monitor anxiety levels in one class and regulate it, with the notion that it might reduce the anxiety levels in the other language classroom and this would produce efficient classrooms as teachers do not need to focus on alleviating stress inside a classroom for each language skills. Pre-meditated precautions in reducing anxiety in one language skills might help students learn their lesson better in the next language lesson. However, the study should be replicated in different demography and samples in order to obtain better validity and providing a solid ground for experimental study to be done in order to employ the possible uses of the correlation between the two skills.

\section{Acknowledgments}

We would like to thank Ministry of Education Malaysia and Research Management Centre, International Islamic University Malaysia for the PRIGS grant awarded to us for this project. 


\section{References}

Ali, J. M. (2000). Verbal Communication: A Study of Malaysian Speakers. Kuala Lumpur, Malaysia: University of Malaya Press.

Ardi Marwan. (2007). Investigating Students' Foreign Language Anxiety. Malaysian Journal Of ELT Research, 3 , 37-55.

Aziz, A. A. A., \& Swanto, S. (2005). ESL TEACHING IN RURAL SCHOOLS: AN INVESTIGATION OF TEACHERS' STRESS AND COPING STRATEGIES. ESL Teaching in Rural Schools: An Investigation of Teachers' Stress and Coping Strategies, 48(9), 800-809. Retrieved from https://digitool.library.mcgill.ca/thesisfile86622.pdf

Darmi, R., \& Albion, P. R. (2015). English Language in Malaysian Education System: Its Existence and Implication, (July 2013).

David, M., Ammon, U., Dirven, R., \& Putz, M. (2012). Teaching of English in Second and Foreign Language Settings: Focus on Malaysia - Duisburger Arbeiten zur Sprach- und Kulturwissenschaft Duisburg Papers on Research in Language and Culture 56 (Paperback).

Department of Statistics Malaysia. (2020). Retrieved from https://www.dosm.gov.my/v1/

Dewaele, J. M., \& Thirtle, H. (2009). Why do some young learners drop foreign languages? A focus on learner-internal variables. International Journal of Bilingual Education and Bilingualism, 12(6), 635-649. https://doi.org/10.1080/13670050802549656

Foo, B., \& Richards, C. (2004). English in Malaysia. RELC Journal, 35(2), 229-240. https://doi.org/10.1177/003368820403500209

Gardner, R. C., \& P. D. Maclntyre. (1989). Anxiety and Second-Language Learning: Toward a Theoretical Clarification*. Language Learning, 39(2), 251-275. https://doi.org/10.1111/j.1467-1770.1989.tb00423.x

Gardner, R., \& Macintyre, P. (1992). A student's contributions to second language learning. Part I: Cognitive Variables. Published online by Cambridge University Press. https://doi.org/10.1017/S026144480000700X

Guan, L. H. (2016). Malaysia's Gallant School System in Need of an Overhaul. ISEAS Perspective, 26(60), 1-8.

Horwitz, E. K., Horwitz, M. B., \& Cope, J. (1986). Foreign Language Classroom Anxiety. The Modern Language Journal, 70(2), 125-132. https://doi.org/10.1111/j.1540-4781.1986.tb05256.x

Hussain, N. E., Nabila, D., \& Abdullah, C. (2018). Macroeconomic Variables and In- Migration in Malaysia' s Developed States ( Migrasi Masuk dan Pembolehubah Makroekonomi bagi Negeri-Negeri Maju di Malaysia). Journal Ekonomi Malaysia, 52(1), 225-241. https://doi.org/10.17576/JEM-2018-5201-19

Islam Ahmad Saiful, S., Yunus, M. M., \& Rahman, H. A. (2017). Pro-Elt: the Unheard Voices of English teachers. Presented at Proceeding: The 8th Regional Seminarat: Universiti Kebangsaan Malaysia (September 2017), 806-822.

Kimura, H. (2008). Foreign language listening anxiety: Its dimensionality and group differences. JALT Journal, 30(2), 173-195. https://doi.org/10.37546/JALTJJ30.2-2

Krashen, S. D. (2006). Principles and Practice in Second Language Acquisition. TESOL Quarterly, 17. https://doi.org/10.2307/3586656

Kwan-Terry, A. (1991). Child Language Development in Singapore and Malaysia. Singapore: Singapore University Press, National University of Singapore.

Landström, P. (2016). Foreign language anxiety among Swedish lower and upper secondary school students.

Lee, S. Y. (2005). Facilitating and inhibiting factors on EFL writing: A model testing with SEM. Language Learning, 55, 335-374. https://doi.org/10.1111/j.0023-8333.2005.00306.x

Leong, L., \& Ahmadi, S. M. (2017). An Analysis of Factors Influencing Learners' English Speaking Skill. International Journal of Research in English Education, 2(1), 34-41. https://doi.org/10.18869/acadpub.ijree.2.1.34

MacIntyre, P. D., \& Gardner, R. C. (1994). The Effects of Induced Anxiety on Cognitive Processing in Second Language Learning. Studies in Second Language Acquisition, 16(1), 1-17. https://doi.org/10.1017/S0272263100012560 
Mak, B. (2011). An exploration of speaking-in-class anxiety with Chinese ESL learners. System, 39(2), $202-214$. https://doi.org/10.1016/j.system.2011.04.002

Md Yunus, M., \& Islam Ahmad Sukri, S. (2017). The Use of English in Teaching Mathematics and Science: The PPSMI Policy vis-à-vis The DLP. Advances in Language and Literary Studies, 8(1), 133. https://doi.org/10.7575/aiac.alls.v.8n.1p.133

Normazidah Che Musa, Khoo, Y. L., \& Hazita Azman. (2012). Exploring English Language Learning And Teaching In Malaysia. GEMA Online Journal of Language Studies, 12(1), $35-51$. https://doi.org/10.1111/j.1944-9720.2007.tb03201.x

Pan, Y. E. (2016). Analysis of Listening Anxiety in EFL Class. International Journal on Studies in English Language and Literature, 4(6), 12-16. https://doi.org/10.20431/2347-3134.0406002

Saito, Y., Horwitz, E. K., Garza, T. J., (1999). Foreign language reading anxiety. Modern Language Journal, 83(2), 202-218. https://doi.org/10.1111/0026-7902.00016

Subramaniam, G. (2007). The Changing Tenor of English in Multicultural Postcolonial Malaysia. 3L Journal of Language Teaching, Linguistics and Literature, 13.

Tan, H. M. (2009). Changing the language of instruction for Mathematics and Science in Malaysia: The PPSMI policy and the washback effect of bilingual high-stakes secondary school exit exams. McGill University. Retrieved from https://digitool.library.mcgill.ca/thesisfile86622.pdf

Thien, L. M., \& Ong, M. Y. (2015). Malaysian and Singaporean students' affective characteristics and mathematics performance: evidence from PISA 2012. SpringerPlus, 4(1). https://doi.org/10.1186/s40064-015-1358-Z

Thirusanku, J., \& Yunus, M. M. (2012). The Many Faces of Malaysian English. ISRN Education, 2012, 1-14. https://doi.org/10.5402/2012/138928

Tsai, C.-C. (2013). The Qualitative Study of Senior Learners' Anxiety of English Listening Comprehension. International Journal of English and Education, 4(3), 131-135.

UNESCO Review, M. E. P. (2013). Malaysia Education Policy Review UNESCO, (May).

Wong, I. F. H., \& H. Thambyrajah. (1991). The Malaysian Sociolinguistic Situation: An Overview" in Child Language Development in Singapore and Malaysia. A. Kwan-Terry (Ed.). Singapore: Singapore University Press.

Woodrow, L. (2006). Anxiety and speaking English as a second language. RELC Journal, 37(3), 308-328. https://doi.org/10.1177/0033688206071315

Wreikat, Y. A., Kabilan, M. K., \& Abdullah, A. C. (2014). The Rural Learning Environment and Pupils' Learning of the English Language. Pertanika Journal of Social Sciences \& Humanities, 22(1), 35-56. 


\section{Appendix}

\section{INSTRUMENT}

This study intends to profile the anxiety level of secondary school students in rural area Selangor in learning the English language. Please answer the following questions with the appropriate answers as indicated by the instructions. Your cooperation is highly appreciated. Your information will only be confidential and only for use in the research.

\section{Section A: Demographic Data}

Age:

Gender:

Race: Malay/Chinese/Indian/Others. If others, please state:

Religion: Islam/Christian/Hindu/Buddhist/Others. If others, please state

School:

Parents' Occupation:

Father's Academic Qualification:

Mother's Academic Qualification:

Number of Siblings: 


\section{Section B}

Please answer the following statements according to the scale. The scales are as followed. 1 for strongly disagree, 2 for disagree, 3 for neutral, 4 for agree and 5 for strongly agree. For each statement, tick the box the appropriate box that represents your response.

\section{Listening Section}

\begin{tabular}{|c|c|c|c|c|}
\hline No. & Statements & 12 & 3 & 4 \\
\hline 1. & When a person speaks English very fast, I worry I might not understand all of it. & & & \\
\hline 2. & $\begin{array}{l}\text { When I'm listening to English, I am worried when I can't watch the lips or facial } \\
\text { expressions of a person who is speaking. }\end{array}$ & & & \\
\hline 3. & I feel uncomfortable in class when listening to English without the written text. & & & \\
\hline 4. & $\begin{array}{l}\text { When I am listening to English, I often get so confused I can't remember what I have } \\
\text { heard. }\end{array}$ & & & \\
\hline 5. & $\begin{array}{l}\text { My thoughts become jumbled and confused when listening to important information } \\
\text { in English. }\end{array}$ & & & \\
\hline 6. & I would rather not to have to listen to people speaking English at all. & & & \\
\hline 7. & I get worried when I can't listen to English at my own pace. & & & \\
\hline 8. & I get worried when I have little time to think about what I have heard in English. & & & \\
\hline 9. & It doesn't frighten me when I cannot catch a keyword of an English listening text. & & & \\
\hline 10. & I don't feel tense when listening to English as a member of social gathering. & & & \\
\hline 11. & $\begin{array}{l}\text { I keep thinking everyone else except me understand very well what an English } \\
\text { speaker saying. }\end{array}$ & & & \\
\hline 12. & $\begin{array}{l}\text { During English lesson, I don't get nervous and confused when I don't understand } \\
\text { every word. }\end{array}$ & & & \\
\hline
\end{tabular}

\section{Reading Section}

13. I become anxious when I have to read English outside of the class for homework.

14. I feel afraid when I have to read lengthy texts in English in English classes.

15. I feel shy when I read in English in front of an audience.

16. Going to English reading class makes me more nervous than going to any other classes.

17. I feel anxious when doing reading tasks when there is no teacher to guide me.

18. It bothers me when many unfamiliar words are used in the reading passage.

19. I become nervous when I find a long sentence with a complex structure that I don't understand.

20. It bothers me when I feel unable to use a dictionary.

21. It embarrasses me to volunteer answers in my reading class.

22. I get afraid if I fail to understand the content of the text that I may be required to read. 


\section{Speaking Section}

23. I never feel quite sure of myself when I am speaking in English.

24. It frightens me when I don't understand what the teacher is saying in English

25. Even if I am well prepared for English classes, I feel anxious it.

26. I don't worry about making mistakes in English classes.

27. I enjoy speaking in English.

28. It does not embarass me to volunteer answers in my English class.

29. I start to panic when I have to speak without preparation in my English class.

30. I always feel that the other students speak better English than I do.

31. I can feel my heart pounding when I'm going to be called on in English language class.

32. In English language class, I can get so nervous where I forget what I wanted to say.

33. I am afraid that the other students will laugh at me when I speak English in class.

34. I would probably feel comfortable around native speakers of English.

35. I get nervous when I don't understand every word the language teacher says.

36. I feel confident when I speak in English.

37. I would not be nervous speaking English with native speakers of English.

38. I feel confident when speaking English in language class.

39. I don't feel pressure when I have to speak English in language classes.

40. I don't feel self-conscious when I speak English in front of other students.

\section{Writing Section}

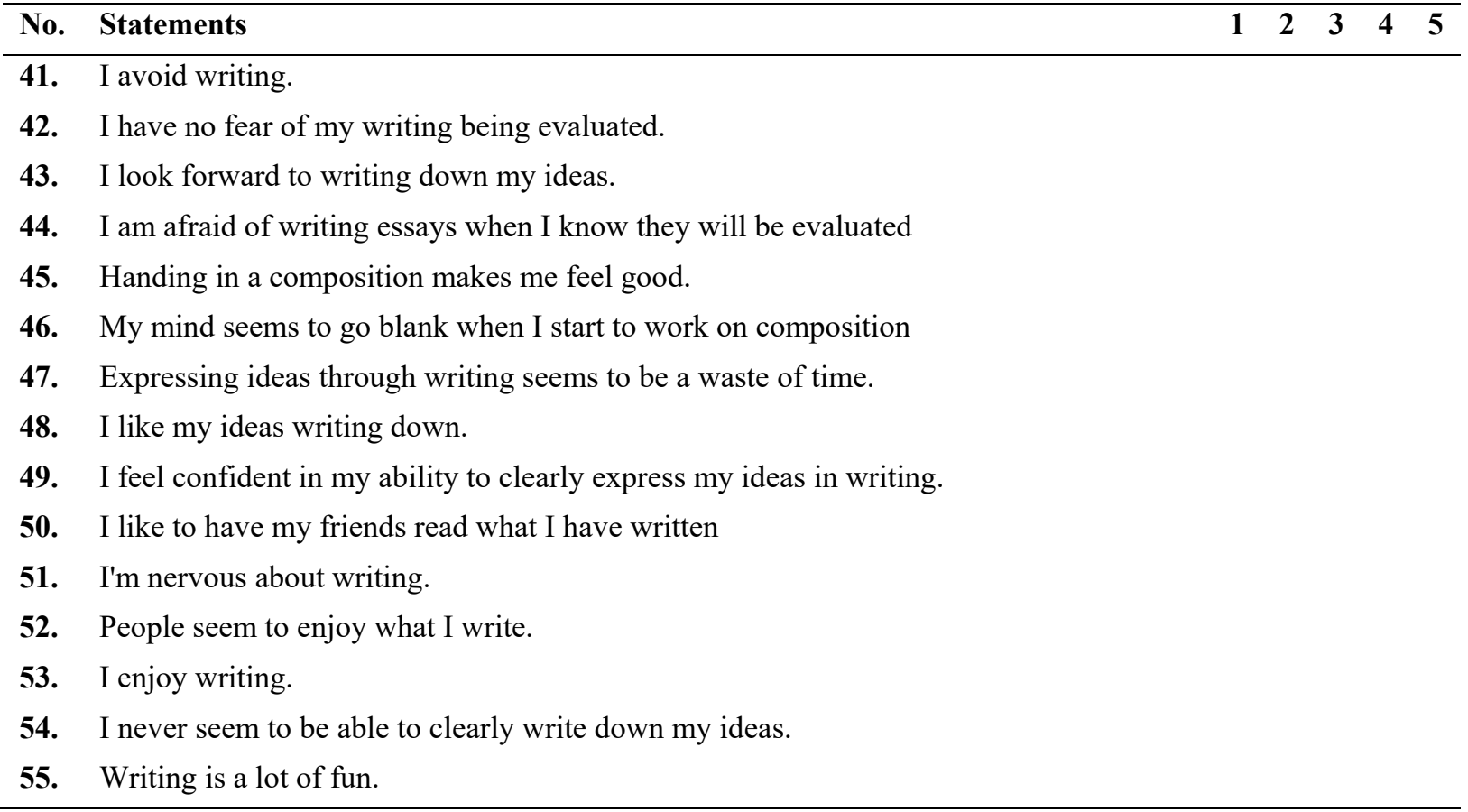

\section{Copyrights}

Copyright for this article is retained by the author(s), with first publication rights granted to the journal.

This is an open-access article distributed under the terms and conditions of the Creative Commons Attribution license (http://creativecommons.org/licenses/by/4.0/). 